\title{
GMR
}

\section{Comparison of two methods for RNA extraction from the nucleus pulposus of intervertebral discs}

\author{
M.F. Gan*, H.L. Yang*, J.L. Qian, C.S. Wu, C.X. Yuan, X.F. Li and J. Zou \\ Department of Orthopaedic Surgery, \\ The First Affiliated Hospital of Soochow University, Suzhou, Jiangsu, China \\ *These authors contributed equally to this study. \\ Corresponding author: J. Zou \\ E-mail: jzou@suda.edu.cn \\ Genet. Mol. Res. 15 (2): gmr. 15027738 \\ Received September 28, 2015 \\ Accepted December 22, 2015 \\ Published June 3, 2016 \\ DOI http://dx.doi.org/10.4238/gmr.15027738
}

\begin{abstract}
RNA extraction from the nucleus pulposus of intervertebral discs has been extensively used in orthopedic studies. We compared two methods for extracting RNA from the nucleus pulposus: liquid nitrogen grinding and enzyme digestion. The RNA was detected by agarose gel electrophoresis, and the purity was evaluated by absorbance ratio using a spectrophotometer. Glyceraldehyde 3-phosphate dehydrogenase (GAPDH) expression was assayed by reverse transcription-polymerase chain reaction (RT-PCR). Thirty human lumbar intervertebral discs were used in this study. The liquid nitrogen-grinding method was used for RNA extraction from 15 samples, and the mean RNA concentration was $491.04 \pm 44.16 \mathrm{ng} / \mu \mathrm{L}$. The enzyme digestion method was used on 15 samples, and the mean RNA concentration was $898.42 \pm 38.64$ $\mathrm{ng} / \mu \mathrm{L}$. The statistical analysis revealed that there was a significant difference in concentration between the different methods. Apparent $28 \mathrm{~S}, 18 \mathrm{~S}$, and $5 \mathrm{~S}$ bands were detectable in RNA extracted using the enzyme digestion method, whereas no $28 \mathrm{~S}$ or $18 \mathrm{~S}$ bands were detected in RNA extracted using the liquid nitrogen-grinding method. The
\end{abstract}


GAPDH band was visible, and no non-specific band was detected in the RT-PCR assay by the enzyme digestion method. Therefore, the enzyme digestion method is an efficient and easy method for RNA extraction from the nucleus pulposus of intervertebral discs for further intervertebral disc degeneration-related studies.

Key words: Nucleus pulposus; RNA extraction; Comparison study

\section{INTRODUCTION}

Reverse transcription-polymerase chain reaction (RT-PCR) is an effective biological technique that is used extensively (Jensen, 2012). RNA extraction is a common operation in RTPCR, and forms the basis for analyzing gene expression. High-quality RNA is a precondition of the success of RT-PCR amplification. Two fundamental ingredients of the nucleus pulposus of intervertebral discs are collagen II and aggrecan (Wu et al., 2014; Oehme et al., 2015). The nucleus pulposus comprises tenacious fibrous connective tissue, and is rich in collagen and aggrecan. However, it contains few cells and is therefore difficult to split. This means that RNA extraction using the conventional method of liquid nitrogen grinding is difficult, which limits further related research. Some novel techniques, such as the cryosection method, have not been used widely owing to the complex manipulation procedure involved (Lee et al., 2015). Type II collagenase mainly affects the collagen molecules of the bone and cartilage, resulting in hydrolysis, but does not affect parenchymal cells. In this study, we sought to use type II collagenase digestion to improve the extraction of total RNA from the nucleus pulposus, and we obtained satisfactory outcomes. By analyzing the outcomes and comparing with the conventional liquid nitrogen-grinding method, this study examined RNA extraction technologies, and summarized reasonable and effective methods to extract total RNA from human lumbar intervertebral discs.

\section{MATERIAL AND METHODS}

\section{General data}

Thirty patients with lumbar intervertebral disc degeneration disease undergoing lumbar decompression between September 2014 and December 2014 were enrolled in this study. Lumbar intervertebral discs were obtained during the surgery and stored at $-80^{\circ} \mathrm{C}$. There were 18 males and 12 females aged 48-68 years (average 58.5 years). Total RNA was separately extracted from the intervertebral discs of 30 patients by two different methods: liquid nitrogen grinding and enzyme digestion. The study was approved by the Ethics Committee of The First Affiliated Hospital of Soochow University, and all patients provided both written and verbal informed consent for participation.

\section{RNA extraction using the liquid nitrogen-grinding method}

Approximately $100 \mathrm{mg}$ nucleus pulposus was obtained and triturated in liquid nitrogen. Briefly, the harvested nucleus pulposus was placed in a pre-cooled mortar, and liquid nitrogen was added for condensing the sample. After liquid nitrogen volatilization, the nucleus 
pulposus was ground into a powder using a pestle. During the period of grinding, liquid nitrogen was added three or four times until the sample had been sufficiently ground. The tissue was then incubated in a centrifuge tube containing $1 \mathrm{~mL}$ Trizol (Invitrogen, Carlsbad, $\mathrm{CA}, \mathrm{USA})$ at $37^{\circ} \mathrm{C}$ for $10 \mathrm{~min}$. Chloroform $(0.2 \mathrm{~mL})$ was then added. After shaking for $15 \mathrm{~s}$ by hand, the sample was incubated at $37^{\circ} \mathrm{C}$ for $10 \mathrm{~min}$, and centrifuged at $12,000 \mathrm{~g}$ and $4^{\circ} \mathrm{C}$ for $15 \mathrm{~min}$. The supernatant was removed to a new Eppendorf tube, and then $0.5 \mathrm{~mL}$ isopropanol was added to precipitate RNA for $10 \mathrm{~min}$ at room temperature. After centrifugation at 12,000 $g$ and $4^{\circ} \mathrm{C}$ for $15 \mathrm{~min}$, the RNA precipitated on the bottom and walls of the tube. After removal of the supernatant, the RNA precipitate was washed once with $1 \mathrm{~mL} \mathrm{75 \%}$ alcohol. The samples were mixed and centrifuged at $7500 \mathrm{~g}$ and $4^{\circ} \mathrm{C}$ for $5 \mathrm{~min}$. After removal of the supernatant, the RNA was dried at $37^{\circ} \mathrm{C}$ for $10 \mathrm{~min}$. The RNA was dissolved with $20 \mu \mathrm{L}$ RNase-free water. After stirring, the sample was stored at $60^{\circ} \mathrm{C}$ for 15 min to promote dissolution.

\section{RNA extraction using the enzyme digestion method}

The nucleus pulposus was cut into pieces, and placed in test tubes. Type II collagenase ( $3 \mathrm{~mL}, 0.2 \%$ ) (Sigma, St. Louis, MO, USA) was added to each tube. The stopper was put back on the bottle, and the bottle was shaken. The sample was digested at $37^{\circ} \mathrm{C}$ for $4 \mathrm{~h}$ in an incubator with 5\% $\mathrm{CO}_{2}$. Phosphate-buffered saline (PBS) $(2 \mathrm{~mL})$ containing $10 \%$ fetal bovine serum was added, stirred, and maintained for $5 \mathrm{~min}$ at room temperature. The supernatant was removed carefully and placed in a $15-\mathrm{mL}$ centrifuge tube, and centrifuged at $1200 \mathrm{~g}$ at room temperature for $40 \mathrm{~s}$. The supernatant was carefully removed to an additional centrifuge tube, to which $5 \mathrm{~mL}$ PBS was added. After stirring and centrifuging at $1200 \mathrm{~g}$ at room temperature for $5 \mathrm{~min}$, the supernatant was carefully discarded. Trizol $(1 \mathrm{~mL})$ was added to the centrifuge tube and stirred. The procedure was conducted on ice. The remaining procedures were identical to the conventional liquid nitrogen-grinding RNA extraction method mentioned above.

\section{Agarose gel electrophoresis}

RNA $(4 \mu \mathrm{L})$ extracted using each of the two methods described above and $1 \mu \mathrm{L}$ nucleic acid loading buffer were electrophoresed on $1 \%$ agarose gel at $100 \mathrm{~V}$ for $20 \mathrm{~min}$.

\section{RNA purity}

Total RNA concentration and quantity were assessed at $260 \mathrm{~nm}$ by measuring the absorbance of samples using a UV-Vis spectrophotometer (Bio Photometer Plus, Eppendorf AG, Hamburg, Germany). The purity of the samples was estimated by the optical density (OD) ratios $\left(\mathrm{A}_{260} / \mathrm{A}_{280}\right.$, range: 1.8-2.2) and was visualized on an agarose gel to verify the quality. $\mathrm{A}$ sample OD ratio of $>1.8$ was regarded as positive.

\section{RT-PCR}

Using a complementary DNA (cDNA) synthesis kit (Invitrogen), the total RNA extracted by the enzyme digestion method was converted to cDNA. RT-PCR was used for mRNA expression analysis using the following primers: GAPDH forward: 5'-CGTGTCAGTGGTGGACCTGACCTG-3',reverse: 5'-GGAGGAGTGGGTGTCGCTGTT 
GAAG-3'. For PCR amplification, $1 \mu \mathrm{L}$ cDNA was combined with $1 \mu \mathrm{L}(10 \mu \mathrm{M})$ upstream and downstream primers, $10 \mu \mathrm{L}$ SYBR Premix ExTaq (2X) (Takara Bio Inc., Otsu, Shiga, Japan), and $7 \mu \mathrm{L}$ distilled water to make a final volume of $20 \mu \mathrm{L}$. The reaction conditions were as follows: initial denaturation at $94^{\circ} \mathrm{C}$ for $3 \mathrm{~min} ; 35$ cycles each of denaturation at $94^{\circ} \mathrm{C}$ for 3 $\mathrm{s}$, annealing at $56^{\circ} \mathrm{C}$ for $30 \mathrm{~s}$ and elongation at $72^{\circ} \mathrm{C}$ for $30 \mathrm{~s}$; followed by a final step at $72^{\circ} \mathrm{C}$ for $10 \mathrm{~min}$. The RT-PCR products were then resolved by electrophoresis on a $1.2 \%$ agarose gel.

\section{Statistical analysis}

All quantitative data are reported as means \pm standard deviation (SD). Statistical analyses were performed using one-way analysis of variance (ANOVA). Differences with $\mathrm{P}<$ 0.05 were considered statistically significant.

\section{RESULTS}

\section{Results of agarose gel electrophoresis}

No $28 \mathrm{~S}$ or $18 \mathrm{~S}$ bands were detected for RNA extracted by the liquid nitrogen-grinding method, but a $5 \mathrm{~S}$ band was partially visible (Figure 1). Apparent 28S, 18S, and $5 \mathrm{~S}$ bands were detected for RNA extracted by the enzyme digestion method. Moreover, the intensity of the $28 \mathrm{~S}$ band was approximately twice that of the $18 \mathrm{~S}$ band (Figure 2).

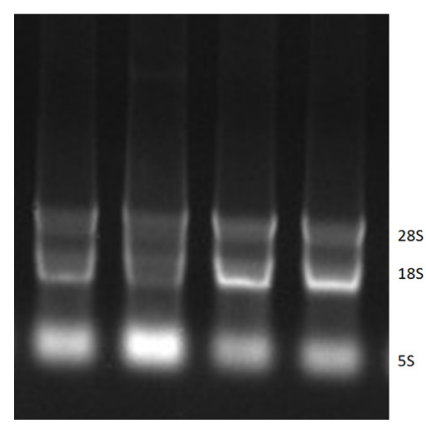

Figure 1. Agarose gel electrophoresis for liquid nitrogen-grinding method. No $28 \mathrm{~S}$ or $18 \mathrm{~S}$ bands were detected in RNA extracted by the liquid nitrogen-grinding method, but a $5 \mathrm{~S}$ band was partially visible.

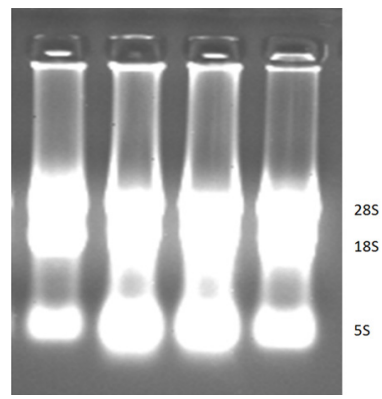

Figure 2. Agarose gel electrophoresis for enzyme digestion method. Apparent 28S, 18S, and 5S bands were detected in RNA extracted by the enzyme digestion method. 


\section{Results of RT-PCR} (Figure 3).

The GAPDH band of 157 bp was visible, and no non-specific band was detected

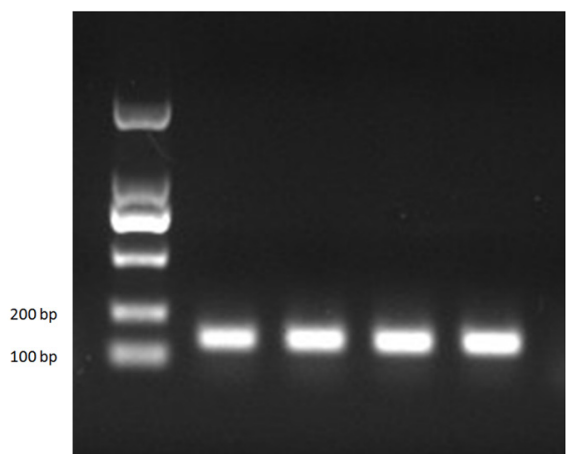

Figure 3. RT-PCR. A glyceraldehyde 3-phosphate dehydrogenase (GAPDH) band of 157 bp was visible, and no non-specific bands were detected by the enzyme digestion method.

\section{Efficiency of RNA extraction}

For the liquid nitrogen-grinding method, the mean RNA concentration was $491.04 \pm$ $44.16 \mathrm{ng} / \mu \mathrm{L}$, mean OD ratio was $1.42 \pm 0.32$, and the positive rate was $21.4 \%$. For the enzyme digestion method, the mean RNA concentration was $898.42 \pm 38.64 \mathrm{ng} / \mu \mathrm{L}$, the mean OD ratio was $1.98 \pm 0.28$, and the positive rate was $100 \%$ (Table 1). The mean RNA concentration obtained using the enzyme digestion method was significantly higher than that using the liquid nitrogen-grinding method $(\mathrm{P}<0.05)$.

Table 1. Efficiency of total RNA extraction.

\begin{tabular}{l|c|c|c}
\hline & RNA concentration $(\mathrm{ng} / \mu \mathrm{L})$ & OD ratio $\left(\mathrm{OD}_{260 / 280}\right)$ & Positive rate $(100 \%)$ \\
\hline Liquid nitrogen-grinding method & $491.04 \pm 44.16$ & $1.42 \pm 0.32$ & 21.4 \\
\hline Enzyme digestion method & $898.42 \pm 38.64$ & $1.98 \pm 0.28$ & 100 \\
\hline
\end{tabular}

$\mathrm{OD}=$ optical density.

\section{DISCUSSION}

RNA extraction from the nucleus pulposus of intervertebral discs has been extensively used in orthopedic experiments (Millward-Sadler et al., 2009). The intervertebral disc is composed of the annulus fibrosus, the nucleus pulposus, and the superior and inferior endplates. Two fundamental ingredients of the nucleus pulposus are collagen (25\%) and proteoglycan (65\%) (Li et al., 2014; Vergroesen et al., 2015). The nucleus pulposus is rich in collagen II and aggrecan, but contains few cells (Yang et al., 2015). Therefore, a method of completely shattering the nucleus pulposus of the intervertebral disc to achieve an effective split, and of elevating the RNA concentration and purity, is very important.

Girotto et al. (2003) successfully extracted RNA from cartilage using the liquid nitrogen-grinding method. However, the intervertebral disc, and other similar fibrous 
connective tissues such as the meniscus, tendon, and ligament, are very tough and cannot be triturated or homogenized. During surgery, the intervertebral disc should be triturated with liquid nitrogen to improve its extraction quality. However, the liquid nitrogen should be added uninterruptedly because liquid nitrogen is volatile at room temperature. Moreover, liquid nitrogen always splashes during trituration, which increases the risk of the operation. The mortar should be immersed in diethylpyrocarbonate for $24 \mathrm{~h}$, followed by autoclaving and drying by baking. The operation is relatively complicated. The results of RNA extraction demonstrated that the OD ratio average was $1.42 \pm 0.32$. The positive rate with OD ratio $>1.80$ was only $21.4 \%$. These results suggest that the lysis was not complete. We found that there were abundant sticky, jelly-like substances on the bottom of the tube. We thought that the jelly-like substances were probably proteoglycans and RNA from the intervertebral disc. RNA extracted by the liquid nitrogen-grinding method contained many impurities, and its purity was not sufficient. Thus, the liquid nitrogen-grinding method was not adequate for RNA extraction from the nucleus pulposus of intervertebral discs.

Collagenases are the only enzymes that affect the helical structure of collagen tissue, and can hydrolyze natural collagen fiber (Murakami et al., 2015). Collagenases act on the chains of the collagen molecule and hydrolyze it into $3 / 4$ and $1 / 4$ fragments at $3 / 4$ of the distance from the amino acid end (Rowan and Young, 2007). Of the collagenases, type I collagenase mainly acts on the collagen fibers of adipose tissues, the adrenal gland, and the liver. Type II collagenase mainly acts on collagen fibers of the heart, bone, thyroid gland, and cartilage, but does not act on parenchymal cells (Kin et al., 2007). Therefore, we used type II collagenase to digest collagen, polysaccharides, and cartilage to obtain pure parenchymal cells. The nucleus pulposus of the intervertebral discs was directly cut into pieces with scissors immediately after the intervertebral disc was obtained, and separately wrapped in tin foil. Thus, the samples could be directly used during extraction, which avoided tissue degradation induced by repeated freezing and thawing. Our experimental results confirmed that the conventional liquid nitrogen-grinding method cannot be utilized to extract intact total RNA from the intervertebral disc. Moreover, the $28 \mathrm{~S}$ and $18 \mathrm{~S}$ bands were not observed; the $5 \mathrm{~S}$ band was partially visible. Using the type II collagenase digestion method, we removed abundant collagen and polysaccharides, obtained many pure parenchymal cells, and extracted highquality RNA. Clear $28 \mathrm{~S}, 18 \mathrm{~S}$, and $5 \mathrm{~S}$ bands were detected, and the intensity of the $28 \mathrm{~S}$ band was significant higher than that of the $18 \mathrm{~S}$ band. The results of RNA extraction demonstrated that the OD ratio average was $1.98 \pm 0.28$. The positive rate was $100 \%$. The results of the electrophoretogram of the GAPDH RT-PCR products presented a noticeable $\beta$-actin band, and no non-specific bands were detected. The UV-Vis spectrophotometer results showed that the purity of nucleic acid extracted by the enzyme digestion was far higher than that extracted by the liquid nitrogen-grinding method.

In summary, RNA extracted by the conventional liquid nitrogen-grinding method was always contaminated with sticky polysaccharides and collagens, so RNA precipitation was negligible. The intervertebral disc contained few cells. Although RNA concentration was $491.04 \pm 44.16 \mathrm{ng} / \mu \mathrm{L}$ on average, it remained lower than that extracted using the enzyme digestion method $(898.42 \pm 38.64 \mathrm{ng} / \mu \mathrm{L})$. The enzyme digestion method to extract total RNA from the intervertebral disc achieved perfect integrity and high purity. Moreover, no pollution of protein, polysaccharides, or collagen was apparent. The enzyme digestion method is, therefore, suitable for analysis and subsequent gene expression, is an effective method for extracting RNA from connective tissue, shows good repeatability, and is worth popularizing. 


\section{Conflicts of interest}

The authors declare no conflict of interest.

\section{ACKNOWLEDGMENTS}

Research supported by the National Natural Science Foundation of China (\#81472132, \#81572183), the Jiangsu Provincial Special Program of Medical Science (\#BL2012004), the Natural Science Foundation of Jiangsu Province (\#BK20130274), and the Priority Academic Program Development of Jiangsu Higher Education Institutions (PAPD).

\section{REFERENCES}

Girotto D, Urbani S, Brun P, Renier D, et al. (2003). Tissue-specific gene expression in chondrocytes grown on three-dimensional hyaluronic acid scaffolds. Biomaterials 24: 3265-3275. http://dx.doi.org/10.1016/S01429612(03)00160-1

Jensen EC (2012). Real-time reverse transcription polymerase chain reaction to measure mRNA: use, limitations, and presentation of results. Anat. Rec. (Hoboken) 295: 1-3. http://dx.doi.org/10.1002/ar.21487

Kin T, Johnson PR, Shapiro AM and Lakey JR (2007). Factors influencing the collagenase digestion phase of human islet isolation. Transplantation 83: 7-12.http://dx.doi.org/10.1097/01.tp.0000243169.09644.e6

Lee JTY, Cheung KMC and Leung VYL (2015). Extraction of RNA from tough tissues with high proteoglycan content by cryosection, second phase separation and high salt precipitation. J. Biol. Methods 2: e20. http://dx.doi.org/10.14440/ ibm. 2015.40

Li SB, Yang KS and Zhang YT (2014). Expression of aquaporins 1 and 3 in degenerative tissue of the lumbar intervertebral disc. Genet. Mol. Res. 13: 8225-8233.http://dx.doi.org/10.4238/2014.October.8.4

Millward-Sadler SJ, Costello PW, Freemont AJ and Hoyland JA (2009). Regulation of catabolic gene expression in normal and degenerate human intervertebral disc cells: implications for the pathogenesis of intervertebral disc degeneration. Arthritis Res. Ther. 11: R65.http://dx.doi.org/10.1186/ar2693

Murakami K, Nakagawa H, Nishimura K and Matsuo S (2015). Changes in peptidergic fiber density in the synovium of mice with collagenase-induced acute arthritis. Can. J. Physiol. Pharmacol. 93: 435-441. http://dx.doi.org/10.1139/ cjpp-2014-0446

Oehme D, Goldschlager T, Ghosh P, Rosenfeld JV, et al. (2015). Cell-based therapies used to treat lumbar degenerative disc disease: a systematic review of animal studies and human clinical trials. Stem Cells Int. 2015: 946031. http:// dx.doi.org/10.1155/2015/946031

Rowan AD and Young DA (2007). Collagenase gene regulation by pro-inflammatory cytokines in cartilage. Front. Biosci. 12: 536-550. http://dx.doi.org/10.2741/2080

Vergroesen PP, Kingma I, Emanuel KS, Hoogendoorn RJ, et al. (2015). Mechanics and biology in intervertebral disc degeneration: a vicious circle. Osteoarthritis Cartilage 23: 1057-1070. http://dx.doi.org/10.1016/j.joca.2015.03.028

Wu DJ, Chen K, Wei XZ, Ni HJ, et al. (2014). Analysis of intervertebral disc-related genes. Genet. Mol. Res. 13: 20322038. http://dx.doi.org/10.4238/2014.March.24.7

Yang H, Cao C, Wu C, Yuan C, et al. (2015). TGF-bl suppresses inflammation in cell therapy for intervertebral disc degeneration. Sci. Rep. 5: 13254.http://dx.doi.org/10.1038/srep13254 